\title{
ISOLATION OF WITHANFERIN-A FROM WITHANIA SOMNIFERA FOR ANTICANCER ACTIVITY AGAINST MCF-7, U373-MG AND OVKAR-3 CELL LINES
}

\author{
R. A. Shah *, S. Khan, M. Vakil and S. L. Nikam \\ Department of Botany, The Institute of Science, 15, Madame Cama Road Mumbai- 400032.
}

*Corresponding Author Email: shahrehanaa@yahoo.com

\begin{abstract}
The isolated Withaferin-A was screened for anticancer activity against MCF-7, U373-MG and OVKAR-3 Cell Lines. The preparative High Performance Thin Layer Chromatography (HPTLC) was used for isolation of Withaferin-A from the leaves of Withania somnifera grown in Karnataka and Nimuch region. The anticancer activity of isolated Withaferin-A was screened in vitro by Sulforhodamine B (SRB) assay considering LC50, TGI, GI50. The results obtained indicate that the anticancer activity of isolated Withaferin-A was found potent growth inhibitor on MCF-7 cell line. The Antiproliferative activity of isolated Withaferin-A gave GI50 values of $<10$, lower than standard Withaferin-A tested and at par with positive control. The anticancer activity of isolated Withaferin-A was comparable with standard Withaferin-A and Adriamycin control (<10ug/ml).
\end{abstract}

\section{KEY WORDS}

Withania somnifera, Withaferin-A, MCF-7, U373-MG, OVKAR-3

\section{INTRODUTION}

Cancer is one of the most severe health problems in both developing and developed countries, worldwide ${ }^{1 \text {, }}$ 2 . When ranked within age groups, cancer is one of the five leading causes of death amongst both males and females and the single largest cause of death worldwide ${ }^{3}$. This growing trend indicates deficiency in the present cancer therapies which include surgical operation, radiotherapy and chemotherapy.

At present, alkylating agents, antimetabolites, antitumor antibiotics, platinum analogs and natural anticancer agents are mostly used in cancer chemotherapy. Since the mortality rate in chemotherapy and radiation therapy is remarkably noticed, discovery of new anticancer agents derived from nature, especially plants, is currently under investigation ${ }^{4,5}$. According to FDA approved anticancer preparations drugs of natural origin have a share of 60$75 \%{ }^{6}$. There are very effective cancer chemotherapeutic drugs that have been derived from natural origin 7 . Vinca alkaloids, vinblastine and vincristine have been reported as potent anticancer agents ${ }^{8}$. Paclitaxel (Taxol), originally isolated from the bark of the Pacific yew tree from the Pacific Northwest, Taxus brevifolia Nutt., and the analogue, docetaxel 9 etoposide and teniposide, derived semi synthetically from epipodophyllotoxin, an epimer of podophyllotoxin, isolated from roots of Podophyllum species ${ }^{10}$.

Withania somnifera is a small, woody shrub which belongs to Solanaceae family. It is commonly known as Indian ginseng or Ashwagandha in Hindi. W. somnifera has been an important herb in the Ayurvedic and indigenous medical systems for over 3000 years. $W$. somnifera possesses a number of therapeutic actions which include anti-inflammatory, sedative, hypnotic, narcotic, general tonic, diuretic, aphrodisiac, alterative, deobstruent 11-18, uterine tonic and increases production of semen ${ }^{12,14,15}$. W. somnifera has been revealed as an immune stimulator in immune suppressed animal models ${ }^{19}$ and also an immune regulator in immune inflammation animal models ${ }^{20}$. 
The active constituents of $W$. somnifera include alkaloids, Withanolide, saponins containing an additional acyl group, flavonoids, and tannins 21, 22, 23 . Over 130 Withanolide are known and more than 40 withanolides, 12 alkaloids, and several sitoindosides were isolated from different parts (leaves, roots and cherries) of $W$. somnifera and their structures were elucidated $24,25,26$. Withanolides are found mainly in leaves and account upto $0.5 \%$ dry weight of the plants depending on the different species ${ }^{27-29}$. More than 45 Withanolides, 5 unidentified alkaloids, many free amino acids, chlorogenic acid, glycosides, glucose, condensed tannins, and flavonoids have been reported in leaves of $W$. somnifera ${ }^{30,16}$. Withaferin-A, a steroidal lactone is the most important withanolide isolated from the extract of the leaves and dried roots of Withania somnifera. Withaferin-A is one of the active constituent for curative properties of the leaves and roots ${ }^{31}$.

Recent in vitro studies have revealed that Withaferin-A inhibit growth of breast and colon cancer cell lines more effectively than did doxorubicin. It suggests that $W$. somnifera extracts may be a potent anticancer agent ${ }^{32}$. This is an exciting finding, suggesting that Ashwagandha could enhance survival in individuals with cancer. Therefore, the present study was undertaken to test anti-cancer activity of isolated Withaferin-A against MCF-7, U373-MG and OVKAR-3 cancer cell lines.

\section{MATERIALS AND METHODS}

\section{Extraction of the plant materials}

Leaves of $W$. somnifera collected from Karnataka and Nimuch region were cleaned, air dried and crushed into coarse powder with mortar and pestle. $10 \mathrm{~g}$ of powdered leaves were extracted respectively with 160 $\mathrm{ml}$ of methanol for $36 \mathrm{hr}$ using Soxhlet apparatus. The extracts were concentrated on water bath to $20 \mathrm{ml}$ and stored in properly labeled clean, dry, screw capped bottles until use ${ }^{33}$.

\section{HPTLC analysis}

\section{Micro-Preparative chromatography}

For Isolation of Withaferin-A from Withania somnifera of previously prepared $40 \mu \mathrm{l}$ plant extracts were loaded as a $160-\mathrm{mm}$ streak on HPTLC plate. The solvent system used was Chloroform: Methanol (9:1). After derivatization, the plates were dried and observed under $254 \mathrm{~nm}$ and $366 \mathrm{~nm}$. Rf values, AUC and $\lambda$ max of
Withaferin-A of the samples were recorded. Withaferin-A band was removed and heated slightly in $2 \mathrm{ml}$ methanol to make the compound diffuse into the solvent and stored overnight in a refrigerator. The following day isolated compound in methanol was filtered through Whatman filter paper 44 and used for analysis. Purity of compound was confirmed by comparing it with standard Withaferin-A and through Mass Spectra.

\section{Bulk Isolation of Withaferin-A}

For bulk isolation of Withaferin-A plant material from Karnataka and Nimuch regions was used since they showed higher quantity of compound. Isolation was performed using a modified method as below.

$1 \mathrm{~g}$ of powdered leaf material of Withania somnifera from the selected regions was extracted three times by the liquid extraction method in an Erlenmeyer flask by shaking on a platform shaker (10-30 rpm) for $8 \mathrm{hrs}$. The solvent used for extraction was methanol: water (10:90). The extracts were recovered by filtration and the filtrates from three extraction system were pooled and liquid-liquid partitioned (three times) with (equal volume) $\mathrm{n}$-hexane to remove pigments and fatty materials. The defatted and depigmented extract was subjected to liquid- liquid partitioning ( 3 times equal volume) to recover withanolidal fraction including Withaferin- $A$ in the chloroform layer. Chloroform fraction of each extract was pooled and evaporated to dryness and was analyzed for anticancer screening ${ }^{34}$. The purity of isolated compound was confirmed by HPTLC.

\section{Antiproliferative activity}

The screening of anticancer activity of Withaferin-A isolated from leaves of $W$. somnifera from Karnataka (WSK-L) and Nimuch (WSN-L) was tested in-vitro by Sulforhodamine B (SRB) method on three Human cancer cell lines viz. MCF-7 (Human-breast adenocarcinoma), U373-MG (Nervous systemglioblastoma) and OVKAR-3 (ovary-Adenocarcinoma). The cell lines we obtained from $\mathrm{NCl}$, USA and NCCS, Pune. Adriamycin was used as a positive control. The test parameters were LC50, TGI, and GI50.

\section{Sulphorhodamine B (SRB) Assay}

The selected cell lines viz. MCF-7, U373-MG and OVKAR-3 were grown in RPMI 1640 medium containing $10 \%$ fetal bovine serum and $2 \mathrm{mM}$ L-glutamine. The cells were inoculated into 96 well micro titer plates in 
$100 \mu \mathrm{l}$ at plating densities. After cell inoculation, the micro titer plates were incubated at $37^{\circ} \mathrm{C}, 5 \% \mathrm{CO}_{2}, 95$ $\%$ air and $100 \%$ relative humidity for $24 \mathrm{~h}$ prior to addition of experimental drugs.

After incubation for $24 \mathrm{~h}$, one 96 well plate containing $5 \times 10^{3}$ cells/well was fixed in situ with TCA, to represent a measurement of the cell population at the time of drug addition ( $\mathrm{Tz}$ ). Experimental drugs were initially solubilized in dimethyl sulfoxide at $100 \mathrm{mg} / \mathrm{ml}$ and diluted to $1 \mathrm{mg} / \mathrm{ml}$ using water and stored frozen prior to use. At the time of drug addition, an aliquot of frozen concentrate $(1 \mathrm{mg} / \mathrm{ml})$ was thawed and diluted to 100 $\mu \mathrm{g} / \mathrm{ml}, 200 \mu \mathrm{g} / \mathrm{ml}, 400 \mu \mathrm{g} / \mathrm{ml}$ and $800 \mu \mathrm{g} / \mathrm{ml}$ with complete medium containing test article. Aliquots of $10 \mu \mathrm{l}$ of these different drug dilutions were added to the appropriate micro titer wells already containing medium.

\section{Endpoint Measurement:}

After $48 \mathrm{hr}$ incubation, the cells were fixed in situ by the gentle addition of $50 \mu \mathrm{l}$ of cold $30 \%(\mathrm{w} / \mathrm{v}$ ) TCA (final concentration, $10 \%$ TCA) and incubated for 60 minutes at $4{ }^{\circ} \mathrm{C}$. The supernatant was discarded and the plates were washed with tap water and air dried. The $50 \mu$ of SRB solution ( $0.4 \%$ ) was added to each of the wells, and plates were incubated for 20 minutes at ambient temperature. After staining, unbound dye was recovered and the residual dye was removed by washing five times with $1 \%$ acetic acid. The plates were air dried and $100 \mu$ l of $10 \mathrm{mM}$ Tris base $\mathrm{pH} 10.5$ (Sigma) were added to each well to solubilize the dye. Bound stain was subsequently eluted with $10 \mathrm{mM}$ trizma base, and the absorbance was read on a plate reader at a wavelength of $540 \mathrm{~nm}$ with $690 \mathrm{~nm}$ reference wavelength. Cell survival was measured as the percentage absorbance compared to that of the control.

\section{RESULT AND DISCUSSION}

The plant biodiversity of India is rich source of natural. Medicinal plants can reduce the toxic side effects of chemotherapy and radiation treatment by reinforcing their killing action. Withaferin-A is one of the major secondary metabolites of $W$. somnifera. Witheferin-A is found maximum in the leaves of plant from Karnataka and Nimuch region ${ }^{35}$. Therefore, in present work, Withaferin-A was isolated from the plants grown in Karnataka and Nimuch region of India were tested for them against studied cell line.

\section{Isolation and confirmation of Withaferin-A}

Withaferin-A isolated by preparative HPTLC method from leaves was confirmed by comparing with the standard peak of Withaferin-A at $223 \mathrm{~nm}$ (Fig.1-2) and Mass spectroscopy with molecular weight 471.6. Scan mode $\mathrm{ES}^{+} 1.05 \mathrm{e} 8$. Moreover, the product ion mass spectra of $\mathrm{m} / \mathrm{z} 471.6$ clearly matched those of the standard which shows the product ion mass spectrum of Withaferin-A in the standard solution $(40 \mu \mathrm{g} / \mathrm{ml})$ and in the sample (Fig.3).

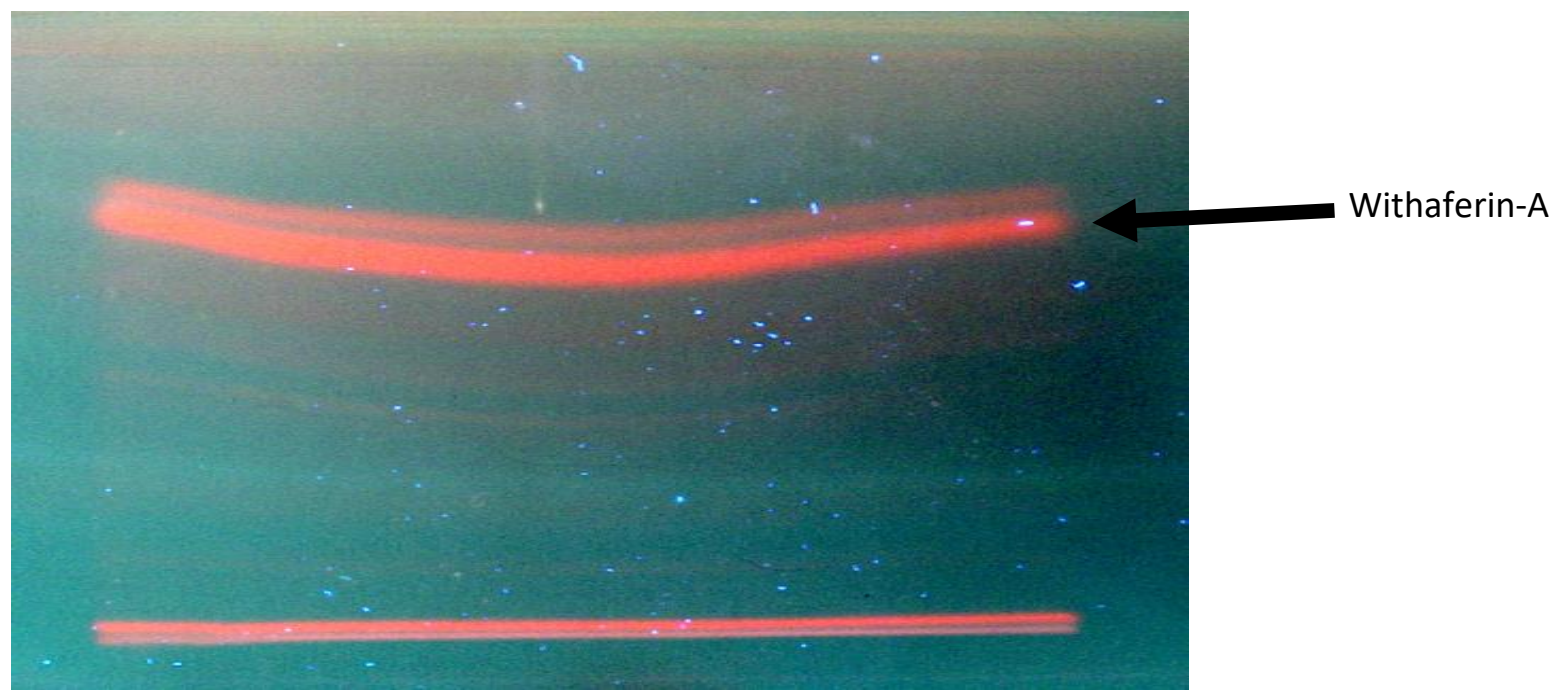

Fig.1: Isolation of Withaferin-A from Withania somnifera leaf Images after derivatization with Anisaldehyde sulphuric acid 


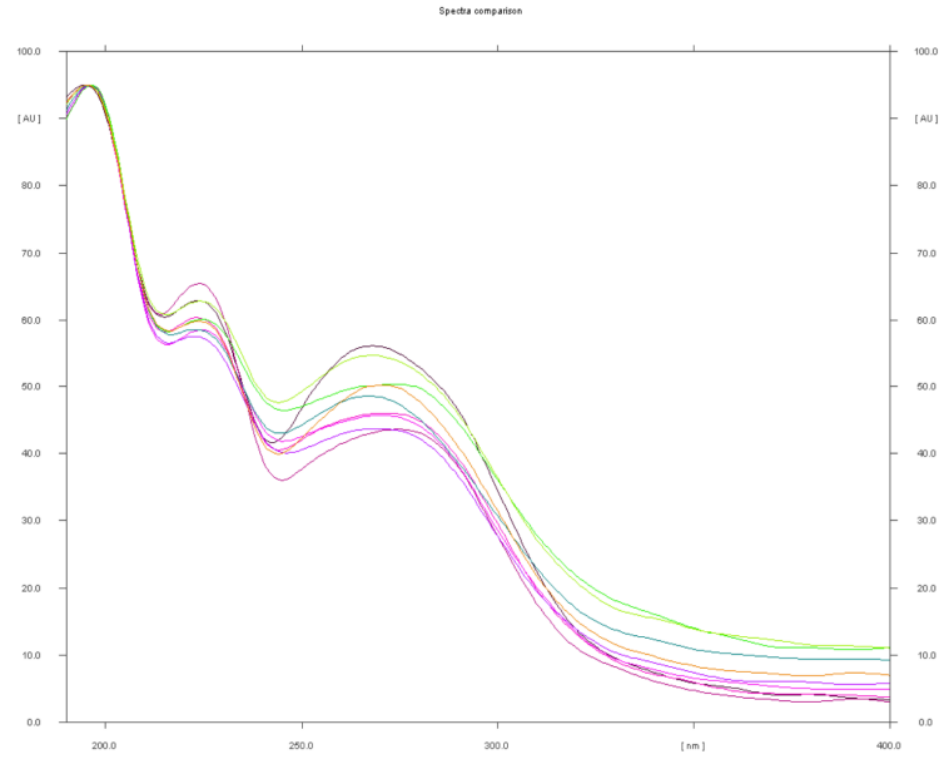

Withaferin-A

Sample 1

Sample 2

Sample 3

Sample 4

Fig.2: $\lambda$ max of $W$. somnifera test samples corresponding to standard Withaferin-A

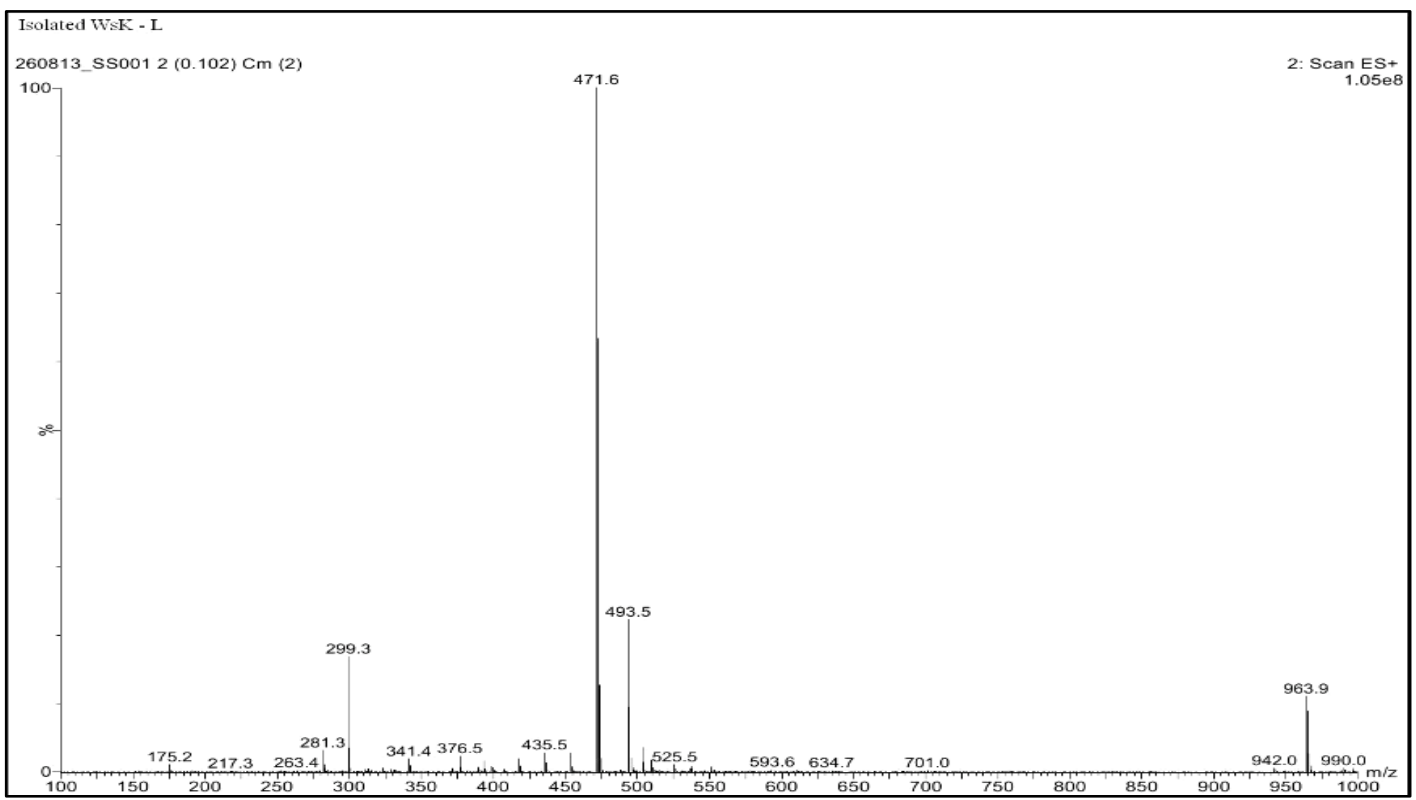

Fig.3: Mass spectra of isolated Withaferin-A from $W$. somnifera leaves

HPTLC method has been used by several workers for isolation and quantification of Withaferin-A. HPTLC method have been validated for simultaneous estimation of $\beta$ - sitosterol, Glucoside and Withaferin-A which can be used for standardizing different Ayurvedic medicines containing Ashwagandha ${ }^{36}$. Withaferin has been quantified using HPTLC in microwave assisted solvent extraction in Withania somnifera ${ }^{37}$. HPTLC is found to be precise and accurate method to estimate the presence of Ashwagandha in herbal formulations (capsule) ${ }^{38}$

\section{Bulk Isolation of Withaferin-A}

Withaferin-A was isolated in bulk from leaf samples of Karnataka and Nimuch by solvent extraction method ${ }^{34}$. The isolated Withaferin-A, was confirmed by comparing $R_{f}$ of standard Withaferin-A using HPTLC.

\section{Anticancer activity of Withaferin-A}

Anticancer activity of isolated Withaferin-A tested on MCF-7. U373-MG, and OVKAR-3 \% growth control, IC50, TGI and GI-50 were determined for each cell line tested. cancer cell lines were tested by Sulforhodamine B (SRB) assay. SRB assay seems to be a preferred method for determining the antiproliferative/ cytotoxicity activity of medicinal plant extracts ${ }^{39}$. SRB assay has been used 
by several workers not only for Withania somnifera ${ }^{40,41}$ but also for other medicinal plants ${ }^{42,43}$.

Withaferin-A isolated sample gave better growth control result on MCF-7 cell line (Table 1; Fig.4). The results obtained against U373-MG cell line gave GI50 values of $<10$, i.e. lower than standard Withaferin-A tested and at par with positive control (Table 2; Fig. 5).
Whereas results obtained in OVKAR-3 cell line were comparable to those obtained with standard Withaferin-A and Adriamycin control (<10ug/ml) (Table 3; Fig.6). The antiproliferative activity in the crude extracts of $W$. somnifera is perhaps due to Withaferin-A and not Withanolide- $A^{44}$.

Table 1: Test parameters calculated from graph for Cell Line MCF-7

\begin{tabular}{llll}
\hline \multicolumn{4}{c}{ Concentrations $(\mu \mathrm{g} / \mathrm{ml})$} \\
\hline Sample code & LC50 & TGI & GI50 \\
\hline ISO-WSN-L & $>80$ & 37.4 & $<10$ \\
ISO-WSK-L & 70.0 & 29.6 & $<10$ \\
ADR & 59.2 & 23.3 & $<10$ \\
\hline
\end{tabular}

[ISO-WSN-L: isolated Withaferin-A from leaf extracts of Nimuch region ISO-WSK-L: isolated Withaferin-A from leaf extracts of Karnataka region ADR: Adriamycin (positive control)]

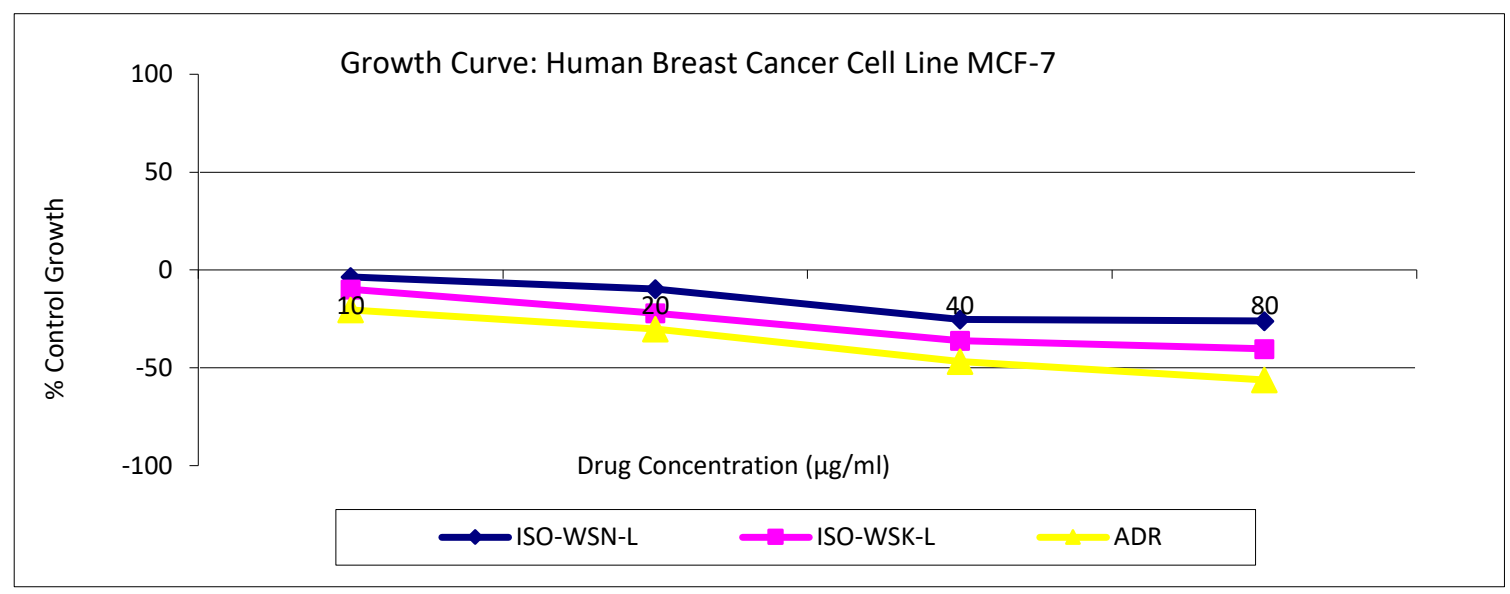

Fig. 4: Antiproliferative activity of Withaferin-A isolated from leaves test samples on human breast cancer cell line (MCF-7)

Table 2. Test parameters calculated from graph for Cell Line U373-MG

\begin{tabular}{llll}
\hline \multicolumn{4}{l}{ Concentrations $(\mu \mathrm{g} / \mathrm{ml})$} \\
\hline Sample code & LC50 & TGI & GI50 \\
\hline ISO-WSN-L & 58.8 & 19.5 & $<10$ \\
ISO-WSK-L & 54.4 & 14.8 & $<10$ \\
ADR & 65.0 & 29.7 & $<10$ \\
\hline
\end{tabular}

[ISO-WSN-L: isolated Withaferin-A from leaf extracts of Nimuch region ISO-WSK-L: isolated Withaferin-A from leaf extracts of Karnataka region ADR: Adriamycin (positive control)] 


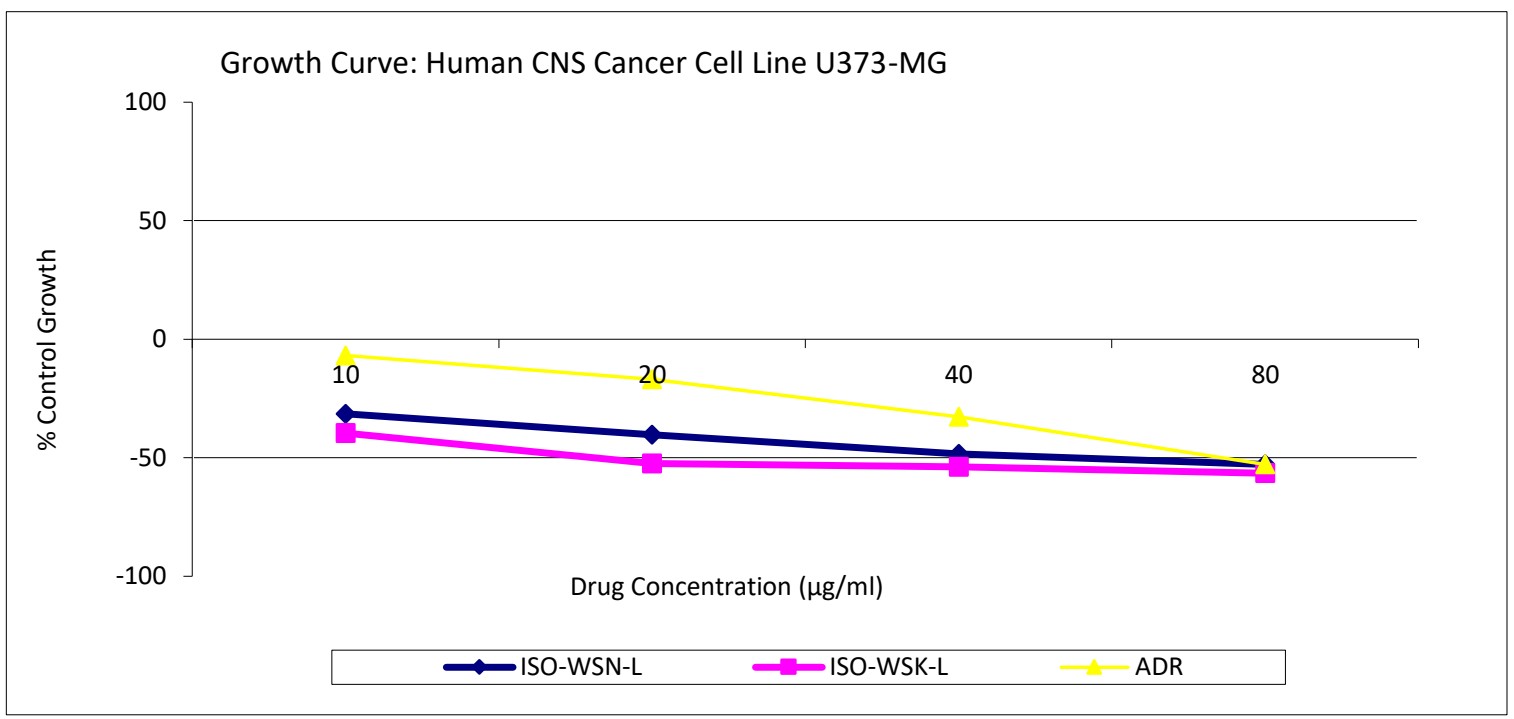

Fig.5: Antiproliferative activity of Withaferin-A isolated from leaves test samples on human CNS cancer cell line (U373-MG)

Table 3. Test parameters calculated from graph for Cell Line OVKAR-3

\begin{tabular}{llll}
\hline \multicolumn{5}{c}{ Concentrations $(\mu \mathrm{g} / \mathrm{ml})$} \\
\hline OVKAR-3 & LC50 & TGI & GI50 \\
ISO-WSN-L & 46.2 & 10.8 & $<10$ \\
ISO-WSK-L & 42.4 & $<10$ & $<10$ \\
ADR & 73.2 & 28.2 & $<10$ \\
\hline
\end{tabular}

[ISO-WSN-L: isolated Withaferin-A from leaf extracts of Nimuch region ISO-WSK-L: isolated Withaferin-A from leaf extracts of Karnataka region ADR: Adriamycin (positive control)]

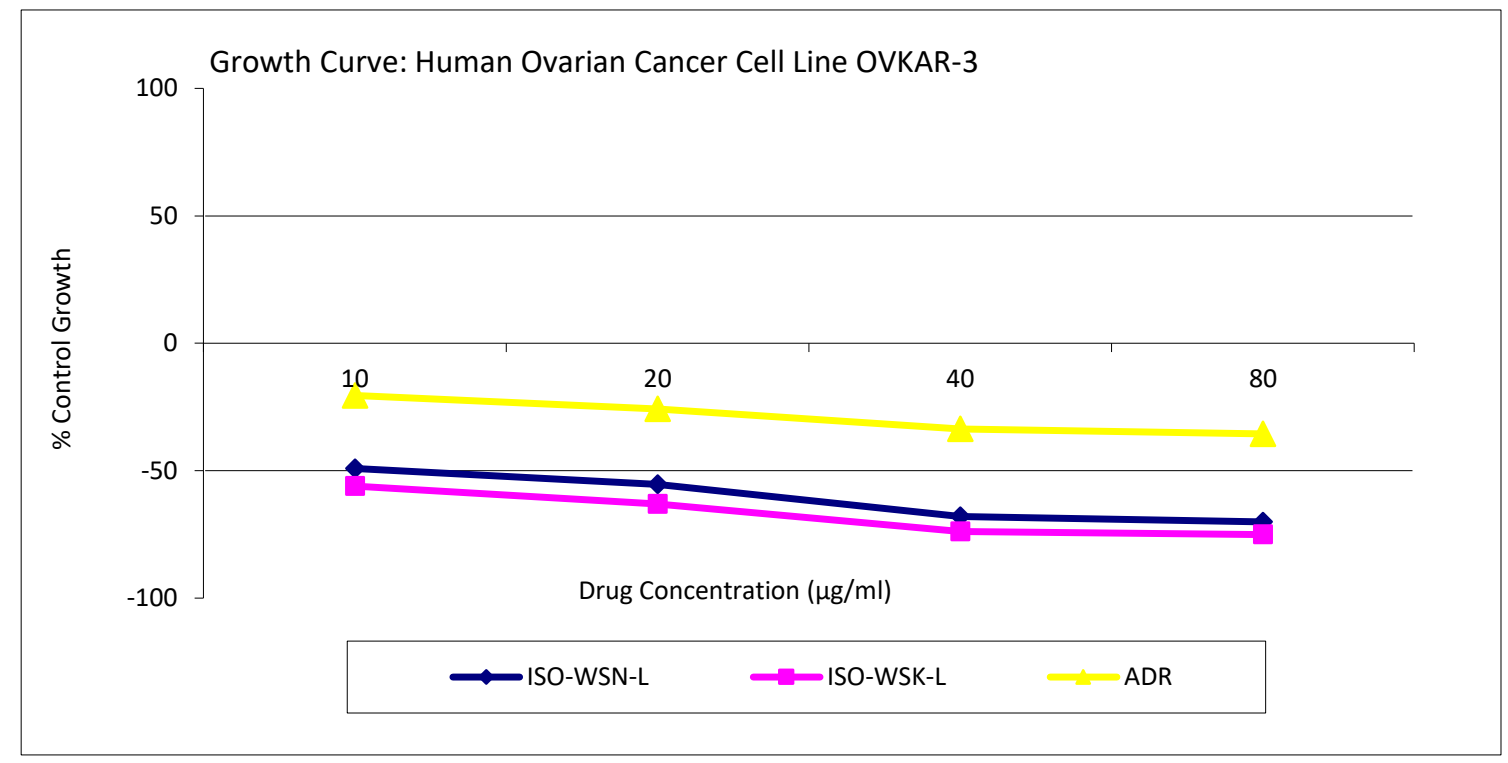

Fig.6: Antiproliferative activity of Withaferin-A isolated from leaves test samples on human ovarian cancer cell line (OVKAR- 3) 


\section{CONCLUSION}

Withaferin-A isolated from Karnataka and Nimuch samples seemed to have potential anticancer activity against studied cell line viz. MCF-7. U373-MG, and OVKAR-3. These findings suggest that Withania somnifera plants cultivated in Nimuch and Karnataka can be exploited to produce novel medicines against this ailment. The present study can be used in future for economical formulations of the active chemical ingredients in natural drugs against cancer.

\section{ACKNOWLEDGMENT}

Authors are thankful to University Grant Commission (UGC), Government of India, New Delhi, for awarding Maulana Azad National Fellowship and we also thank Director, The Institute of Science, Mumbai and Dr. A.S. Juvekar, Advance Centre for Treatment, Research \& Education in Cancer (ACTREC), Kharghar, Navi Mumbai for their support and help.

\section{REFERENCES}

1. Itharat $\mathrm{A}$, Houghton PJ, Eno-Amooquaye $\mathrm{E}$, Burke PJ, Sampson JH, Raman A. (2004). In vitro cytotoxic activity of Thai medicinal plants used traditionally to treat cancer J Ethnopharmacol. 90. 33-38

2. Sehgal A. (2003). Anticancer drug discovery using chemical genomics. Current Med Chemistry. 10(9). 749755

3. Jemal A, Siegel R, Ward E, Hao Y, Xu J, Murray T, Thun M.J. (2008). Cancer statistics. CA Cancer J Clin. 58. 7196

4. Ho J.W., Leung Y.K., Chan C.P. (2002). Herbal medicine in the treatment of cancer. Curr Med Chem Anticancer Agents. 292. 209-214

5. Ravelo Á.G., Estévez-Braun A, Chávez-Orellana H, PérezSacau E, Mesa-Siverio D. (2004). Recent studies on natural products as anticancer agents. Curr Top Med Chem. 4. 241-265

6. Newman D.J., Cragg G.M., Snader K.M. (2003). Natural products as sources of new drugs over the period 19812002. J Nat Prod. 66(7). 1022-1037

7. Lee K.H. (2010). Discovery and development of natural product-derived chemotherapeutic agents based on a medicinal chemistry approach. J Nat Prod. 73. 500-516

8. Cragg G.M. and Newman D.J. (2005). Plants as a source of anti-cancer agents, Journal of Ethnopharmacology. 100. $72-79$

9. Cragg G.M. (1998). Paclitaxel (TaxolW): a success story with valuable lessons for natural product drug discovery and development. Med Res Rev. 18. 315-331
10. Lee K.H. and Xiao Z. (2005). Podophyllotoxins and analogs. In Anticancer Agents from Natural Products. Edited by Cragg GM, Kingston DGI, Newman DJ. Boca Raton, Florida: Taylor \& Francis Group. 71-88.

11. Ali S.S. (1997). Unani Advia-e-Mufradah. $8^{\text {th }}$ Ed. National Council for Promotion of Urdu Language (NCPUL), New Delhi. 33.

12. Anonymous. (2007). The Unani Pharmacopoeia of India. Part I, Vol. I, Department of AYUSH, Ministry of Health \& Family Welfare, Govt. of India, New Delhi. 7-8.

13. Chopra R.N., Nayar S.L. and Chopra I.C. (1080). Glossary of Indian Medicinal Plants. Council of Scientific \& Industrial Research, New Delhi. 191, 258

14. Ghani N.(1920). Khazainul Adviyah. Vol. I, Munshi Nawal Kishore, Lucknow. 230-231

15. Kabiruddin M. (1955). Makhzan-ul-Mufradat. Nadeem University Printers, Lahore. 75-76

16. Khare C.P. (2007). Indian Medicinal Plants-An Illustrated Dictionary. First Indian Reprint, Springer (India) Pvt. Ltd., New Delhi. 717- 718

17. Kirtikar K.R. and Basu B.D. (1980). Indian Medicinal Plants. $2^{\text {nd }}$ Ed. Vol. III, Lalit Mohan Basu, Allahabad, India. 1774-1777

18. Nadkarni K.M. (1982). Indian Materia Medica. $3^{\text {rd }}$ Ed. Vol. I, Popular Prakashan Pvt. Ltd., Bombay. 1292-1294

19. Ziauddin M., Phansalkar N., Patki P., Diwanay S. and Patwardhan B. (1996). Studies on the immunomodulatory effect of Asgandh. J Ethnopharmacol. 50 (2). 69-76

20. Agarwal R., Diwanay S., Patki P. and Patwardhan B. (1999). Studies on immunomodulatory activity of Withania somnifera (Ashwagandha) extracts in experimental immune inflammation. J Ethnopharmacol. 97. 27-35

21. Mishra LC, Singh BB and Dagenais S. (2000). Scientificbasis for the therapeutic use of Withania somnifera (Ashwagandha), a review. Altern. Med. Rev. 5:334-346

22. Kuo P.C., Kuo T., Damu A.G. et al. (2006). Physanolide A, a novel skeleton steroid, and other cytotoxic principles from Physalis angulata. Org Lett. 8. 2953-2956.

23. Bandyopadhyay M., Jha S. and Tepfer D. (2007). Changes in morphological phenotypes and withanolide composition of Ri-transformed roots of Withania somnifera. Plant Cell Rep. 26. 599-609

24. Kulkarni S.K. and Dhir A. (2008). Withania somnifera: an Indian ginseng. Prog Neuropsychopharmacol Biol Psychiatry. 32. 1093-105

25. Tursunava R.N., Maslennikova V.A. and Abubakirov N.K. (1977). Withanolides in the vegetable kingdom Chem Nat Comp. 13. 131-138

26. Matsuda H., Murakami T., Kishi A. and Yoshikawa M (2001). Structures of withanosides I, II, III, IV , V, VI, and 
VII, new withanolide glycosides, from the roots of Indian Withania somnifera DUNAL. and inhibitory activity for tachyphylaxis to clonidine in isolated guinea-pig ileum. Bioorg Med Chem. 9. 1499-1507

27. Kapoor L.D. (2001). Handbook of Ayurvedic Medicinal Plants. CRC Press: London, UK: 337-338

28. Atal C.K.G., Ranghunathan O.P. and Dhar K.L. (1975). Central Council for Research in Indian Medicine and Homeopathy. New Delhi, India.

29. Anonymous. (2004). Monograph. Withania somnifera. Altern Med Rev. 9. 211-214

30. Bhattacharya S.K., Kumar A. and Ghosal S. (1995). Effects of glycoWithanolides from Withania somnifera on an animal model of Alzheimer's disease and perturbed central cholinergic markers of cognition in rats. Phytother Res. 9. 110.

31. Anonymous, (2004). Monograph:Withania somniferaAlternative Medicine Review. Vol. 9, No. 2

32. Prakash J., Gupta S.K. and Dinda A.K. (2002). Withania somnifera root extract prevents DMBA induced squamous cell carcinoma of skin in Swiss albino mice. Nutr. Cancer. 42. 91-97

33. Trease G.E. and Evans M.C. (1989). Textbook of pharmacognosy, $13^{\text {th }}$ Ed Bailliere, Tindal, London. 683684

34. Sangwan R.S., Chaurasiya N.D., Misra L.N., Lal P., Uniyal G.C., Sangwan N.S., Srivastava A.K., Suri K.A., Qazi G.N. and Tuli R. (2006). Process for isolation of withaferin-A from plant materials and products therefrom. United State Patent: patent no. US 7108870 B2 Date of patent sep.19

35. Rehana A. S. and Shahana K. (2012). Evaluation of Withaferin-A in Ashwagandha's Leaves from Different Climatic Regions of India. Ad Plant Sci. 25(II). 709-711

36. Jirge S.S., Tatke P.A. and Gabhe S.Y. (2011). Development and validation of a novel HPTLC method for simultaneous estimation of beta sitosteroldglucoside and WithaferinA. International Journal of Pharmacy and Pharmaceutical Sciences. 0975-1491

37. Jyothi D., Khanam S. and Sultana R. (2010). Optimization of microwave assisted solvent extraction of Withanolides from leaves of Ashwagandha Pharmacie Globale. 4 (01). 1-5

38. Soni K. and Naved T. (2010). HPTLC - Its applications in herbal drug industry. The Pharma Review. 112-117

39. Skehan P., Storeng R., Scudiero D., Monks A., McMahon I., Vistica D., Waren J.T., Bokesch H., Kenney S. and Boyd M.R. (1990). New colo- rimetric cytotoxicity assay for anticancer drug screening. J Natl. Cancer Inst. 82.11071112

40. Gaidhani S.N., Singh A., Kumari S., Lavekar G.S., Juvekar A.S., Sen S. and Padhi M.M. (2013). Evaluation of some plant extracts for standardization and anticancer activity. 12. 682-687

41. Yadav B., Bajaj A., Saxena M. and Saxena A.K. (2010). In Vitro Anticancer Activity of the Root, Stem and Leaves of Withania Somnifera against Various Human Cancer Cell Lines. Indian Journal of Pharmaceutical Sciences. 72(5). 659-663

42. Saetung A., Itharat A., Dechsukum C., Wattanapiromsakul C., Keaw Niwat Keawpradub and Pranee R., 2005. Cytotoxic activity of Thai medicinal plants for cancer treatment. J Sci Technol. 27. 469-478

43. Pandey K., Sharma P.K. and Dudhe R. (2012). Anticancer Activity of Parthenium hysterophorus Linn and Oldenlandia corymbosa Lam by SRB Method. Open Access Scientific Reports. 1(6). 325

44. Shah R.A., Khan S. and Vakil M. (2016). 'Antiproliferative Activity of Methanolic Root Extract of Withania somnifera against MCF-7, HCT-15, U373-MG and OVKAR3 Cell Lines.' Int J Green \& Herbal Chem, Sec. B. 5(3). 206214
*Corresponding Author:

R. A. Shah

Email:shahrehanaa@yahoo.com 